\title{
Fiscal and Monetary Policy, Output and Price in Indonesia: An Effectiveness Approach
}

\author{
Alpon Satrianto \\ Dept. of Economics, Faculty of Economics, Universitas Negeri Padang, Padang, Indonesia \\ $\square$ (e-mail) alpon.unp@gmail.com
}

\begin{abstract}
The purpose of this research is to analyze the most effective policy on output and price. From several literature studies that have been done by many economists only see the effectiveness of fiscal and monetary policy on output alone. No authors find the effectiveness of fiscal and monetary policy on prices. Though macroeconomic variables are not only output but there are many other macroeconomic variables. One such macroeconomic variable is price. The data in this study is in the form of time series from 1970-2015. Fiscal policy uses data of real government expenditure, monetary policy uses real money supply data, output use real GDP data, and prices using Consumer Price Index data (CPI). Data analysis techniques use Vector Auto Regressive (VAR), Impulse Response Function (IRF) and Forecast Error Variance Decomposition (FEVD). A policy is said to be effective if the FEVD method shocks one policy against output variability and the price is greatest compared to other policies. The conclusions of this study indicate that Fiscal Policy is more effective against output and prices in Indonesia compared to Monetary Policy. The effectiveness of Fiscal Policy compared to Monetary Policy can be seen from the contribution of shock Fiscal Policy to the variability of output and prices greater than Monetary Policy. Based on these conclusions, it is suggested to the government through the relevant ministries and Bank Indonesia always maintains the interaction and synergy between Fiscal Policy and monetary to macroeconomic variables. Keywords: fiscal, monetary, output, and price
\end{abstract}

\section{Introduction}

Increased production of goods and services (output), and the existence of price stability is a macroeconomic goal to be achieved by a country. In order to achieve these objectives as expected, a country's government needs to take appropriate actions and policies in accordance with certain conditions. This policy is known as macroeconomic policy in the form of fiscal policy and monetary policy. The effectiveness of appropriate fiscal and monetary policies is no longer an option, but a necessity in the face of various macroeconomic phenomena and challenges. The effectiveness of this policy is not just the coordination and interaction between the policies, but how these policies are effective in overcoming these economic challenges and phenomena. Why not, a challenging digital era and competition require effective policy support for a country's economy to compete rapidly with other countries.

The theory of the effectiveness of fiscal and monetary policy was initiated by Classical theory and Keynesian theory. Both theories have different views on the effectiveness of those policies in the economy. The Classical Theory developed by the Monetarist (Neo-classical) further emphasizes the use of monetary policy in overcoming economic problems. This opinion is based on the idea that the effect of monetary policy on aggregate demand is immediate. Extra cash will not necessarily be bought on securities, but directly spent in goods. Fiscal policy in this case is considered less effective in influencing the economy given the effects of crowding out in the policy (Romer, 2011).

Keynesian theory has a different opinion from the classical theory. The theory which was later developed by the modern Keynesian stream emphasized that monetary policy had an impact on the economy through several channels (transmission mechanism). These lines tend to cause the effects of monetary policy to be uncertain. Keynes put more emphasis on the use of fiscal policy in the 
economy. This is based on his opinion that, first the elasticity of money demand on the interest rate is very small (the extreem is zero) so that the IS curve is upright. Expansive fiscal policy will shift the IS curve right so that the output increases. While monetary expansion with the addition of money supply on an upright IS curve will not affect the output. This shows that fiscal policy will be more effective than monetary policy (Romer, 2011).

Some empirical studies show that on the one hand fiscal policy has a greater impact on the economic activities of a country. On the other hand, it appears that the real fiscal policy has a dominant influence on economic activity in some countries. Khosravi \& Karimi (2010), Abata, Kehinde, \& Bolarinwa (2012), Fetai (2013), Cyrus (2014), Okorie, Sylvester \& Simon-peter (2017) fiscal policies that are more effective in boosting output or economic growth. In particular, government spending is urgently needed when the economy is sluggish. While Ajayi (1974); Ajisafe \& Folorunso (2002); Fatima \& Iqbal (2003); Rahman (2004); Ali \& A, (2008); Weeks (2008); Younus (2008); Adefeso, H.A (2010); Jawaid et al. (2010); Senbet (2011); Snyder \& Bruce (2011); Moses \& Asare (2013); Rakic \& Redenovic (2013); Yunanto \& Medyawati, (2014); Sen (2015) suggests that monetary policy is more effective in influencing economic growth.

From some previous theories and research presented above, it appears that fiscal and monetary policies have an effective impact on economic output or growth. From one side of fiscal policy is considered effective and on the other hand monetary policy is considered effective. However, previous theories and studies only examine one macroeconomic variable of a country. None of these theories and previous studies examined how the effectiveness of fiscal and monetary policies against other macroeconomic objectives such as price. This is important to be studied considering macroeconomic goals not only at the level of output alone. Therefore, this paper will analyze how the effectiveness of fiscal and monetary policy on output and price in Indonesia.

\section{Methods}

The data in this study started from 1970 - 2015 with the amount of data (n) of 46. The data obtained from the Central Bureau of Statistics and Bank Indonesia. The data obtained from the Central Bureau of Statistics is the output data measured from the value of Gross Domestic Product at Constant Price Base Year (2010) in million Rupiah. While the price is measured from Consumer price index. Fiscal policy is measured from real government expenditure and monetary policy is measured from the real money supply (M2) each in million Rupiah.

The analysis method used in this research is Vector Autoregression (VAR) / Vector Error Correction Model (VECM). A policy is said to be effective when the shock of a policy toward an endogenous variable is the largest of its role (in percent) compared to other policies (Darsono, 2008) (Nuryati, Siregar, \& Ratnawati, 2006). The VAR / VECM equation model as follows.

1. Effectiveness of fiscal and monetary policies on output

$$
\begin{gathered}
Y_{t}=\alpha_{1 i}+\sum_{i=1}^{n} \beta_{1 i} Y_{t-i}+\sum_{i=1}^{n} \theta_{1 i} G_{t-i}+\sum_{i=1}^{n} \lambda_{1 i} M s_{t-i}+\varepsilon_{1 t} \\
G_{t}=\alpha_{1 i}+\sum_{i=1}^{n} \beta_{1 i} Y_{t-i}+\sum_{i=1}^{n} \theta_{1 i} G_{t-i}+\sum_{i=1}^{n} \lambda_{1 i} M s_{t-i}+\varepsilon_{2 t} \\
M s_{t}=\alpha_{1 i}+\sum_{i=1}^{n} \beta_{1 i} Y_{t-i}+\sum_{i=1}^{n} \theta_{1 i} G_{t-i}+\sum_{i=1}^{n} \lambda_{1 i} M s_{t-i}+\varepsilon_{3 t}
\end{gathered}
$$

2. Effectiveness of fiscal and monetary policies on prices

$$
\begin{aligned}
& P_{t}=\alpha_{1 i}+\sum_{i=1}^{n} \beta_{1 i} P_{t-i}+\sum_{i=1}^{n} \theta_{1 i} G_{t-i}+\sum_{i=1}^{n} \lambda_{1 i} M s_{t-i}+\varepsilon_{1 t} \\
& G_{t}=\alpha_{1 i}+\sum_{i=1}^{n} \beta_{1 i} P_{t-i}+\sum_{i=1}^{n} \theta_{1 i} G_{t-i}+\sum_{i=1}^{n} \lambda_{1 i} M s_{t-i}+\varepsilon_{2 t}
\end{aligned}
$$




$$
M s_{t}=\alpha_{1 i}+\sum_{i=1}^{n} \beta_{1 i} P_{t-i}+\sum_{i=1}^{n} \theta_{1 i} G_{t-i}+\sum_{i=1}^{n} \lambda_{1 i} M s_{t-i}+\varepsilon_{3 t}
$$

\section{Results and Discussion}

\section{The Effectiveness of Fiscal and Monetary Policy on Output}

The first step taken to analyze the effectiveness of fiscal and monetary policy on output is a stationary test. From the stationary test conducted, it turns out that fiscal policy variables, monetary policy and output are not stationary at the level because the probability value of each variable is greater than 0.05 at the level. Therefore, the stationary test is performed at the $1^{\text {st }}$ difference stage. All variables are stationary at $1^{\text {st }}$ difference caused by probability value of each variable is small from 0,05 . This condition is shown in Table 1 .

Table 1 Stationary test variables fiscal, monetary policy and output

\begin{tabular}{lcc}
\hline \multirow{2}{*}{ Variables Name } & $\begin{array}{c}\text { Augmented Dickey- } \\
\text { Fuller Test Statistic }\end{array}$ & Conclusion \\
\cline { 2 - 2 } & Probability & Stasioner \\
\hline Fiscal Policy $(\mathrm{G})$ & 0.0006 & Stasioner \\
\hline Monetary Policy (Ms) & 0.0079 & Stasioner \\
\hline Output $(\mathrm{Y})$ & 0.0162 & . \\
\hline
\end{tabular}

The next step is to perform optimal lag test. Optimal lag selection is important because it can affect the acceptance and rejection of the null hypothesis, resulting in estimation bias and can produce inaccurate predictions. The methods used to determine the optimal lag are Likelihood Ratio (LR), Final Prediction Error (FPE), Akaike Information Criteria (AIC), Schwarz Information Criterion (SIC), and Hannan Quinn Information Criterion (HQ) with minimum values. From table 2 it can be seen that the minimum value of all these criteria appears in many lag 1 . Therefore, it can be said that the optimum lag on this model uses lag 1.

Table 2 Optimal lag test of the effectiveness of fiscal and monetary policy on output

\begin{tabular}{ccccccc}
\hline Lag & LogL & LR & FPE & AIC & SC & HQ \\
\hline 0 & -2129.458 & NA & $4.06 \mathrm{e}+42$ & 106.6229 & $106.7496^{*}$ & 106.6687 \\
\hline 1 & -2115.642 & $24.86887^{*}$ & $3.20 \mathrm{e}+42^{*}$ & $106.3821^{*}$ & 106.8887 & $106.5653^{*}$ \\
\hline 2 & -2109.925 & 9.433047 & $3.80 \mathrm{e}+42$ & 106.5462 & 107.4329 & 106.8668 \\
\hline 3 & -2104.327 & 8.397215 & $4.60 \mathrm{e}+42$ & 106.7163 & 107.9830 & 107.1743 \\
\hline 4 & -2094.840 & 12.80716 & $4.68 \mathrm{e}+42$ & 106.6920 & 108.3386 & 107.2874 \\
\hline 5 & -2082.982 & 14.22954 & $4.34 \mathrm{e}+42$ & 106.5491 & 108.5757 & 107.2819 \\
\hline
\end{tabular}

The next step is to test the stability of VAR / VECM. This test is done so that the result of IRF and FEVD obtained valid. The stability of the VAR / VECM system is seen from the inverse roots of its polynomial AR characteristics. If all AR-roots values are within the circle, then the VAR / VECM system can be said to be stable or vice versa. Figure 1 shows that all the nominal AR modulus values are within the circle. Thus, it can be said that the VAR system in this model is a stable VAR. A stable VAR will produce valid and correct IRF and FEVD analysis.

Next is the cointegration test. This test is used to determine whether there will be a long-term balance, i.e. there is a similarity of movement and relationship stability among the variables in the study or not. If the model is cointegrated then the model is analyzed by the VECM method, but if the model is not cointegrated then the model is analyzed by VAR. Table 3 shows that the three hypotheses in this equation have a probability value greater than 0.05 . Since the probability value for the three hypotheses in this equation is large from 0.05 it can be stated that this equation is not cointegrated. Thus, the effectiveness model of Fiscal Policy and monetary to output can be estimated with VAR model $1^{\text {st }}$ difference. 


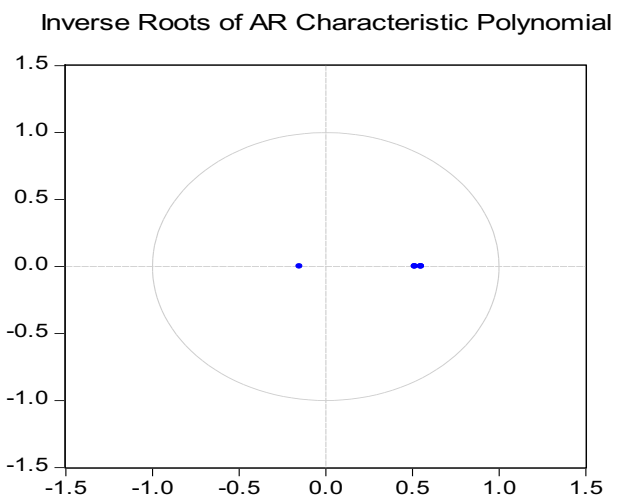

Figure 1 Value of AR roots of the effectiveness of fiscal and monetary policy on output

Next, an Impulse Response Function (IRF) analysis used to see the effect of shock from a variable on other variables. A shock in the endogenous variable will affect the variable itself and will spread to other endogenous variables. IRF gives direction the relationship of magnitude influence between endogenous variables. Estimates made for IRF are focused on the response of a variable on the change of one standard deviation from the variable itself or from other variables contained in the VAR model.

Table 3 Cointegration test of the effectiveness of fiscal and monetary policy on output

\begin{tabular}{|c|c|c|c|c|}
\hline $\begin{array}{c}\text { Hypothesized } \\
\text { No. of CE(s) }\end{array}$ & Eigenvalue & $\begin{array}{c}\text { Trace } \\
\text { Statistic }\end{array}$ & $\begin{array}{c}0.05 \\
\text { Critical Value } \\
\end{array}$ & Prob. $^{* *}$ \\
\hline None & 0.012535 & 0.789917 & 29.79707 & 1.0000 \\
\hline At most 1 & 0.005161 & 0.234907 & 15.49471 & 1.0000 \\
\hline At most 2 & 0.000164 & 0.007228 & 3.841466 & 0.9318 \\
\hline
\end{tabular}

Figure 2 (A) shows the response to the change in output due to a shock Fiscal Policy. The presence of shock from the Fiscal Policy towards the change of output response initially tends to decrease the change in output until the $7^{\text {th }}$ period but after that period, the output response moves closer to the equilibrium line. Therefore, the shock of Fiscal Policy toward output will disappear and not permanently in the long run. A similar condition is shown by the output response due to Monetary Policy shock in Figure 2 (B). Shock Monetary Policy causes the output response to decrease until the $6^{\text {th }}$ period. Then after that, the output response approaches the equilibrium line. This means Monetary Policy shock also does not permanently affect the output.
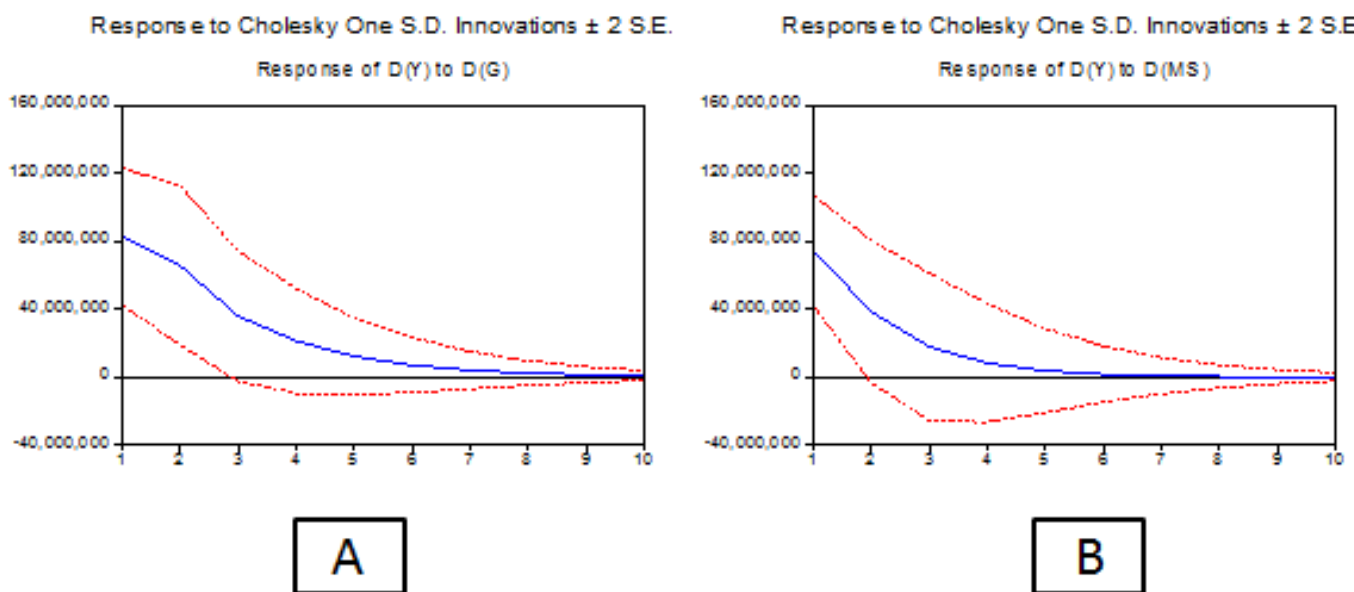

Figure 2 Output response due to shock fiscal (A) and monetary (B) policy 
To see and analyze the effectiveness of Fiscal Policy and monetary to the output seen from the value of Forecast Error Variance Decomposition (FEVD). Table 4 shows that in general the variability of output both in the short term and long term can be explained by the shock of the Fiscal Policy of $39.19 \%$ and in the long term by $41.16 \%$. While the variability of output in the short term is explained by Monetary Policy shock equal to $24,68 \%$ and in long term equal to $23,31 \%$. This condition concludes that the most effective policy towards the change of output in Indonesia is Fiscal Policy. This can be seen from the contribution of Fiscal Policy to the greatest output variability compared to the Fiscal Policy contribution.

Table 4 FEVD Test Model of The Effectiveness of Fiscal and Monetary Policy on Output

\begin{tabular}{ccccc}
\hline $\begin{array}{c}\text { Variance } \\
\begin{array}{c}\text { Decomposition } \\
\text { of } \mathrm{D}(\mathrm{Y}):\end{array}\end{array}$ & S.E. & $\mathrm{D}(\mathrm{G})$ & $\mathrm{D}(\mathrm{MS})$ & $\mathrm{D}(\mathrm{Y})$ \\
\cline { 1 - 5 } Period & & & & \\
\hline 1 & $1.46 \mathrm{E}+08$ & 32.13087 & 26.07004 & 41.79910 \\
\hline 2 & $1.68 \mathrm{E}+08$ & 39.19004 & 24.68350 & 36.12645 \\
\hline 3 & $1.75 \mathrm{E}+08$ & 40.47555 & 23.87715 & 35.64729 \\
\hline 4 & $1.77 \mathrm{E}+08$ & 40.93969 & 23.52960 & 35.53071 \\
\hline 5 & $1.78 \mathrm{E}+08$ & 41.09008 & 23.39387 & 35.51605 \\
\hline 6 & $1.78 \mathrm{E}+08$ & 41.14001 & 23.34430 & 35.51568 \\
\hline 7 & $1.78 \mathrm{E}+08$ & 41.15621 & 23.32700 & 35.51679 \\
\hline 8 & $1.78 \mathrm{E}+08$ & 41.16141 & 23.32114 & 35.51746 \\
\hline 9 & $1.78 \mathrm{E}+08$ & 41.16305 & 23.31920 & 35.51775 \\
\hline 10 & $1.78 \mathrm{E}+08$ & 41.16357 & 23.31857 & 35.51786 \\
\hline
\end{tabular}

The effectiveness of fiscal policy rather than monetary policy on output in Indonesia due to the impact of fiscal policy is directly to the real sector. When the government increases its spending such as capital expenditure and infrastructure, this condition will directly affect the increase of goods and services production. Especially in times of crisis and recession increased government spending is a policy that is eagerly awaited by market participants in order to provide excitement in the production. This condition is also reinforced by aggregate demand theory which shows that government spending along with consumption, investment and net exports affect the ups and downs of output. The theory also asserts that there is a positive relationship between government spending on output. Increased government spending has implications for increased output. Increased output will encourage increased output.

Monetary policy is seen as less effective in this study rather than interpreting that monetary policy so far in Indonesia has no effect on output, but the point is the role of monetary policy during the study period is less than the fiscal policy. This condition is due to the monetary policy in Indonesia in influencing the output is not directly but through some path or stage known as the transmission mechanism. This transmission mechanism is a complex process because of many factors that influence it. These factors include 1) changes in the behavior of central banks, banks and economic actors in their various economic and financial activities, (2) the length of lags since monetary policy is adopted, and 3) changes in transmission lines monetary itself in accordance with economic and financial developments.

Any change in central bank policy will be followed or anticipated by changes in banking behavior, financial sector and economic actors in various economic and financial activities. On the other hand, the monetary policy taken during this period will not have any effect on the output of this period but also the deadline. Then, the more paths the monetary policy will go through will further weaken the impact of the policy in influencing output. 
The results of this study are in accordance with the studies that have been done by Chowdhury (1986), Ansari (1996), Khosravi \& Karimi (2010), Abata, Kehinde, \& Bolarinwa (2012), Fetai (2013), Cyrus (2014), Okorie, Sylvester, \& Simon-peter (2017) who concluded that fiscal policy is more effective in encouraging economic activity. The addition of fiscal policy will be able to drive aggregate demand increase so that the impact on output increase.

\section{The Effectiveness of Fiscal and Monetary Policy on Prices}

Similar to the above tests, the first step to analyze the effectiveness of Fiscal Policy and monetary price is the stationary test. From stationary test conducted, it turns out that Fiscal Policy, Monetary Policy and Prices variable is not stationary at the level because the probability value of each variable is greater than 0.05 at the level. Therefore, the stationary test is performed at the 1st difference stage. In stage 1st difference, all variables are stationary this is indicated by the probability value of each variable is small from 0.05 . This condition is shown in table 5 .

Table 5 Stationary test fiscal policy, monetary and prices

\begin{tabular}{lcc}
\hline \multirow{2}{*}{ Variable } & $\begin{array}{c}\text { Augmented Dickey- } \\
\text { Fuller test statistic }\end{array}$ & Conclusion \\
\cline { 2 - 2 } & Probability & \\
\hline Fiscal Policy $(\mathrm{G})$ & 0.0006 & Stasioner \\
\hline Monetary Policy $(\mathrm{Ms})$ & 0.0079 & Stasioner \\
\hline Prices $(\mathrm{P})$ & 0.0005 & Stasioner \\
\hline
\end{tabular}

In this model, the minimum value of the optimal lag test criteria shows different lag values. Therefore, then taken one of the criteria that is the minimum AIC value. Table 6 shows that the minimum AIC value is in lag 4. Thus, the optimal lag value in this model uses lag 4 .

Table 6 Optimal lag test results of the effectiveness of fiscal and monetary policy on prices

\begin{tabular}{ccccccc}
\hline Lag & LogL & LR & FPE & AIC & SC & HQ \\
\hline 0 & -1440.510 & NA & $4.45 \mathrm{e}+27$ & 72.17548 & 72.30215 & 72.22128 \\
\hline 1 & -1398.179 & 76.19566 & $8.42 \mathrm{e}+26$ & 70.50894 & $71.01560^{*}$ & $70.69213^{*}$ \\
\hline 2 & -1393.016 & 8.519134 & $1.03 \mathrm{e}+27$ & 70.70078 & 71.58744 & 71.02137 \\
\hline 3 & -1378.390 & $21.93789^{*}$ & $7.93 \mathrm{e}+26$ & 70.41952 & 71.68618 & 70.87750 \\
\hline 4 & -1368.034 & 13.98111 & $7.72 \mathrm{e}+26^{*}$ & $70.35170^{*}$ & 71.99836 & 70.94708 \\
\hline 5 & -1363.483 & 5.461128 & $1.03 \mathrm{e}+27$ & 70.57415 & 72.60081 & 71.30693 \\
\hline
\end{tabular}

The VAR / VECM stability test is then performed. The VAR / VECM model of Fiscal Policy and monetary effectiveness against these prices is a stable model. This is seen from the nominal AR value residing in the circle as shown in Fig. 3. In the sense that the VAR / VECM model is a stable model.

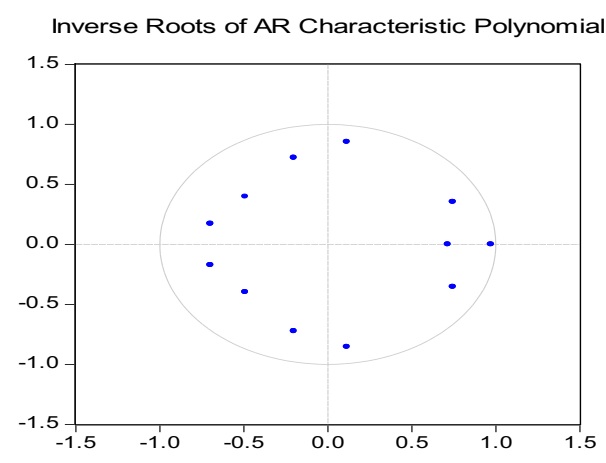

Figure 3 Value of AR roots of the effectiveness of fiscal and monetary policy on prices 
Then, the cointegration test shows that this model is an unintegrated model. This condition is seen from table 6 which shows the three hypotheses in this equation has a probability value greater than 0.05. By means of words, the effectiveness model of Fiscal Policy and monetary to the price can be estimated with VAR $1^{\text {st }}$ difference model.

Table 7 Cointegration test model of the effectiveness of fiscal and monetary policy on prices

\begin{tabular}{ccccc}
\hline $\begin{array}{c}\text { Hypothesized } \\
\text { No. of CE(s) }\end{array}$ & Eigenvalue & $\begin{array}{c}\text { Trace } \\
\text { Statistic }\end{array}$ & $\begin{array}{c}0.05 \\
\text { Critical Value }\end{array}$ & Prob.** $^{* *}$ \\
\hline None & 0.002438 & 0.111940 & 29.79707 & 1.0000 \\
\hline At most 1 & 0.000205 & 0.011874 & 15.49471 & 1.0000 \\
\hline At most 2 & $8.44 \mathrm{E}-05$ & 0.003462 & 3.841466 & 0.9513 \\
\hline
\end{tabular}

Furthermore, the result of IRF Fiscal Policy and monetary effectiveness towards the prices indicates that the shock Fiscal Policy initially responded by the prices with the increase then decreased until the $4^{\text {th }}$ period. Furthermore, it increases again until the $7^{\text {th }}$ period. In the $10^{\text {th }}$ period the response of prices approaches the equilibrium line. This means that response prices begin to disappear in the period to 10 due to the shock Fiscal Policy. This condition is shown in Figure 4 (A).

Response to Cholesky One S.D. Innovations \pm 2 S.E.

Response of $D(P)$ to $D(G)$

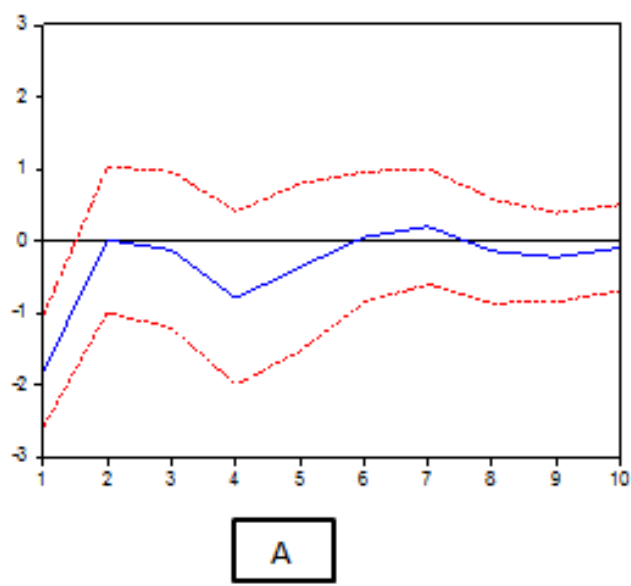

Response to Cholesky One S.D. Innovations \pm 2 S.E.

Response of $D(P)$ to $D(M S)$

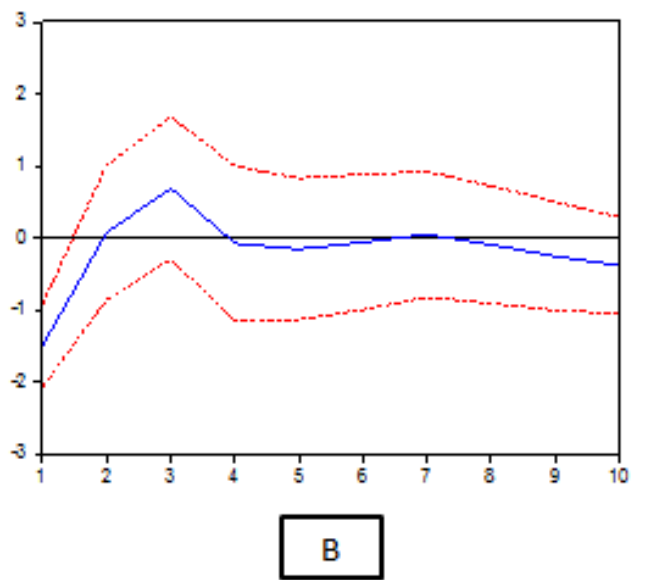

Figure 4 Prices response due to shock fiscal policy (A) and monetary policy (B)

Similar to the shock of Fiscal Policy on prices, shock Monetary Policy initially also showed an increase in prices with a positive value. It then decreases in the $3^{\text {rd }}$ period and approaches the equilibrium line. This impact is also not permanent in the long term. This is shown in Figure 4 (B).

The results of the Fiscal Policy and monetary effectiveness tests against the prices indicate that the Fiscal Policy is more effective against the variability of prices than the Monetary Policy. Table 8 shows that both in the short term and in the long run the contribution of the shock fiscal policy is greater than the contribution of the Monetary Policy shock. In the short term, the Fiscal Policy's contribution to the variability of prices is $41.70 \%$ and in the long term $31.68 \%$. While the Monetary Policy in the short term contributed $28.52 \%$ shock to the variability of prices and in the long term amounted to $22.67 \%$.

The effectiveness of fiscal policy rather than monetary policy on prices in Indonesia is due to the direct effect of fiscal policy on the real sector which has an impact on increasing the production of goods and services. Increase in government expenditures in the form of capital expenditures, personnel goods, infrastructure spending and others will trigger an increase in the money supply. This if not controlled will cause inflation. 
Table 8 FEVD test model of the effectiveness of fiscal and monetary policy on prices Variance

\begin{tabular}{ccccc}
$\begin{array}{c}\text { Decomposition } \\
\text { of } \mathrm{D}(\mathrm{P}):\end{array}$ & S.E. & $\mathrm{D}(\mathrm{G})$ & $\mathrm{D}(\mathrm{MS})$ & $\mathrm{D}(\mathrm{P})$ \\
\cline { 1 - 5 } Period & & & & \\
\cline { 1 - 5 } 1 & 2.783079 & 41.70261 & 28.52551 & 29.77187 \\
\hline 2 & 2.842697 & 39.97714 & 27.41874 & 32.60412 \\
\hline 3 & 3.147561 & 32.75524 & 27.23877 & 40.00598 \\
\hline 4 & 3.391077 & 33.62888 & 23.50828 & 42.86284 \\
\hline 5 & 3.432876 & 33.88952 & 23.12748 & 42.98300 \\
\hline 6 & 3.459311 & 33.40162 & 22.79716 & 43.80122 \\
\hline 7 & 3.498336 & 33.00321 & 22.31545 & 44.68134 \\
\hline 8 & 3.530632 & 32.54967 & 21.97281 & 45.47752 \\
\hline 9 & 3.566724 & 32.27337 & 22.01458 & 45.71205 \\
\hline 10 & 3.603227 & 31.68190 & 22.67347 & 45.64463 \\
\hline
\end{tabular}

Although the ultimate goal of monetary policy in Indonesia is controlled prices, the results of this study show that monetary policy is less effective than fiscal policy in influencing prices. This condition is due to the effect of monetary policy takes a long time to anticipate price increase. The monetary policy transmission lines make the monetary policy effect difficult to achieve. Thus, when the government increases its spending precisely in the short run the price increases. In the long run, new monetary policy reactions can be realized in controlling prices.

\section{Conclusions}

The conclusions of this study indicate that fiscal policy is more effective against output and prices in Indonesia compared to monetary policy. The effectiveness of fiscal policy compared to monetary policy can be seen from the contribution of shock fiscal policy to the variability of output and prices greater than monetary policy.

Based on these conclusions, it is suggested to the government through the relevant ministries and Bank Indonesia always maintains the interaction and synergy between fiscal policy and monetary to macroeconomic variables. The interaction and synergy between these policies is necessary so that these two policies avoid mutually exclusive issues.

Fiscal policy has proven to be more effective against output and price variables. Therefore, the government and all related parties to prioritize Fiscal Policy in responding to the fluctuation of output and prices in Indonesia. After that, then the government supports with the monetary policy. When output falls, the government prioritizes fiscal policy by increasing its expenditure. Like increasing infrastructure projects, lowering taxes, providing affordable business loans to small and medium enterprises and others so that this condition will add to the smooth production of goods and services. Certainly, it will ultimately have an impact on increasing output. After that, then Bank Indonesia through its policy instrument to increase the money supply through the decline of interest rates. Reduced interest rates will reduce the burden of investor funds so that will encourage increased investment. Increased investment will contribute to increased output.

\section{References}

Abata, M. A., Kehinde, J. S., \& Bolarinwa, S. A. (2012). Fiscal/monetary policy and economic growth in Nigeria: A Theoretical Exploration. International Journal of Academic Research in Economics and Management Sciences, 1(5), 75-88.

Adefeso, H.A, \& H. . M. (2010). Adefeso. 2010. The fiscal and monetary policy on economi growth in Nigeria.pdf. Pakistan Journal of Social Sciences, 7, 137-142.

Ali, S. I. S., \& A, A. (2008). Whether fiscal stance or monetary policy is effective for economic growth 
in case of South Asian countries. The Pakistan Development Review, 47(4), 791-799.

Cyrus, M. (2014). Monetary and fiscal policy shocks and economic growth in Kenya: VAR econometric approach, 3(6), 95-108. http://doi.org/10.11648/j.jwer.20140306.14

Fetai, B. (2013). The effectiveness of fiscal and monetary policy during the financial crisis, XVI(2), 5366.

Jawaid, S. T., Arif, I., \& Naeemullah, S. M. (2010). Comparative analysis of monetary and fiscal policy: A case study of Pakistan. MPRA Paper No. 30850, (30850). Retrieved from http://mpra.ub.unimuenchen.de/30850/

Khosravi, A., \& Karimi, M. S. (2010). To investigation the relationship between monetary, fiscal policy and economic growth in iran: Autoregressive distributed lag approach to cointegration. American Journal of Applied Sciences, 7(3), 415-419. http://doi.org/10.3844/ajassp.2010.415.419

Musa, Y., \& Asare, B. K. (2013). Long and short run relationship analysis of monetary and fiscal Policy on economic growth in Nigeria : A VEC model approach, 5(10), 3044-3051.

Okorie, D. I., Sylvester, M. A., \& Simon-peter, D. C. (2017). Relative effectiveness of fiscal and monetary policies in nigeria, 2(1). http://doi.org/10.20849/ajsss.v2i1.129

Rahman, H. (2004). Relative effectiveness of monetary and fiscal policies on output growth in bangladesh : A VAR approach. Bangladesh Journal of Political Economy, 22, 419-440.

Rakic, B., \& Redenovic, T. (2013). The Effectiveness of monetary and fiscal policy in Serbia. Industrija, 41(2), 103-122. http://doi.org/10.5937/industrija41-4011

Romer, D. (2011). Advanced Macroeconomics (4th ed.). New York: MCGraw-Hill.

Sen, H. \& A. K. (2015). The relative effectiveness of monetary and fiscal policies on growth: What does longrun SVAR model tell us?

Senbet, D. (2011). The relative impact of fiscal versus monetary actions on output: A vector autoregressive (VAR) approach. Business and Economic Journal, 25, 1-11.

Snyder, T. C., \& Bruce, D. (2011). Tax cuts and interest rate cuts: An empirical comparison of the effectiveness of fiscal and monetary policy. Journal of Business $\mathcal{E}$ Economics Research, 2(8), 1-12.

Weeks, J. (2008). The Effectiveness of monetary policy reconsidered. Centre for development policy and research, School of Oriental and African Studies, 3(3), 1-20.

Younus, S. (2008). Relative effectiveness of monetary and fiscal policies on output growth in bangladesh: A co integration and vector error correction approach.

Yunanto, M., \& Medyawati, H. (2014). Monetary and fiscal policy analysis: Which is more effective? Journal of Indonesian Economy and Business, 29(3), 222-236. 